\title{
Rancang Bangun dan Analisa Pengendali CCTV Berbasis Arduino Menggunakan Smartphone Android
}

\author{
Oscar Ade Astra $^{1)}$ Yesi Mardiana ${ }^{2)}$ \\ 1) Mahasiswa, Universitas Dehasen Bengkulu \\ Jl. Meranti Raya No. 32 Kota Bengkulu 38228 Telp. (0736) 22027, 26957 Fax. (0736) 341139; e-mail: \\ oscarade26@gmail.com) \\ ${ }^{2)}$ Dosen Tetap Program Studi Sistem Komputer Fakultas Ilmu Komputer Universitas Dehasen Bengkulu \\ J1. Meranti Raya No. 32 Kota Bengkulu 38228 Telp. (0736) 22027, 26957 Fax. (0736) 341139
}

\begin{abstract}
The problems that have arisen recently have increased the importance of cetv remote control that supports and facilitates the avoidance of accidents while operating. This study aims to control cetv using applications from smartphones for remote control connected to the bluetooth module. Hardware and software used Dual-Core AMD Processor C50-1 Ghz Hard drive 320 GB, ATI Radeon HD 6250 Graphics RAM 2.00 GB DDR3 Memory windows 7 operating system, arduino two servo motor control software and V380 software. This research uses laboratory research method and literature study. Research through practice and testing. Experiments include programming language test, electronic component test and computer hardware test suitable for research implementation. The result of cetv Bluetooth control analysis with Arduino nano-based android smartphone, this controller uses Arduino nano as a Bluetooth control system, the Bluetooth module is used as an acceptance command sent via android smartphone, servo motor functioned as a controlled cetv drive using Android Smartphone using Arduino two servo motors control. Based on testing of Bluetooth connection on cetv controller can be concluded for range of Bluetooth connection distance between smartphone and Bluetooth controller to be controlled completely with range of \pm 25 meter, 25-40 to suffer signal less and dashed, and more than 40-meter range will experience disconnected connection can not be controlled anymore.
\end{abstract}

Keywords: Controller cctv, Bluetooth

Intisari - Berbagai persoalan yang muncul pada akhir-akhir ini meningkatkan bahwa betapa pentingnya kendali jarak jauh cetv yang mendukung dan memberi kemudahan menghindari kecelakaan saat beroperasi. Penelitian ini bertujuan untuk mengendalikan cctv yang menggunakan aplikasi dari smartphone unruk pengendalian jarak jauh yang terkoneksi ke modul bluetooth. Instrumen perangkat keras dan lunak yang digunakan Processor AMD Dual-Core C50-1 GhzHarddisk 320 GB,VGA ATI Radeon HD 6250 graphics RAM 2.00 GB DDR3 Memory sistem operasi windows 7, software arduino two servo motor control dan software V380. Penelitian ini menggunakan metode penelitian laboratorium dan studi pustaka. Penelitian yang melaluipraktikum dan uji coba. Percobaan yang dilakukan meliputi test bahasa pemrograman, uji komponen elektronika dan uji perangkat keras komputer yang cocok untuk pelaksanaan penelitian. Hasil analisa kendali cctv Bluetooth dengan smartphone android berbasis Arduino nano, pada pengendali ini menggunakan Arduino nano sebagai sistem pengendalian Bluetooth, modul Bluetooth digunakan sebagai penerimaan perintah yang dikirim melalui smartphone android, motor servo difungsikan sebagai penggerak cetv yang dikendalikan menggunakan Smartphone Android menggunakan aplikasi Arduino two servo motors control.Berdasarkan pengujian koneksi Bluetooth pada pengendali cetvdapat disimpulkan untuk jangkauan jarak koneksi Bluetooth antara smartphone dan pengendali Bluetooth untuk bisa dikendalikan sepenuhnya dengan jarak jangkauan $\pm \mathbf{2 5}$ meter, untuk 25-40 mengalami sinyal yang kurang dan putus-putus, dan lebih dari jangkauan 40 meter akan mengalamai koneksi terputus tidak bisa dikendalikan lagi.

Kata kunci :Pengendali cctv, Bluetooth

\section{Pendahuluan}

\section{A. Latar Belakang}

Pada era globalisasi seperti saat ini perkembangan teknologi sangat pesat, teknologi yang terjadi pada alat banyak dioperasikan secara manual, sehingga kurang efisiennya dalam waktu, tenaga dan keakuratannya. Seperti yang kita ketahui sekarang ini perkembangan teknologi sangat pesat, baik itu dalam bidang pendidikan, industri, kesehatan dan lain sebagainya. Dimana dapat kita lihat banyaknya alat-alat industri, rumah tangga, kesehatan yang serba modern.

Hal ini juga terjadi pada dunia wira usaha, yang mana banyak peralatan wira usaha yang sudah menggunakan sistem komputer. Akan tetapi masih banyak juga yang masih dilakukan atau dikerjakan secara manual. Peralatan wira usaha yang sudah terkomputerisasi misalnya peralatan berangkas uang di 
meja kasir dan lain sebagainya. Dan peralatan yang masih manual seperti CCTV di Atm Maupun dilaboratorium dan lain-lain.

Selaras dengan perkembangan jaman, dibutuhkan kendali CCTV yang otomatis menggunakan bluetooth HC-06, bekerja secara otomatis dan bisa dikedalikan,saat berada di ruangan terbuka bisa dikendalikan tanpa harus memutar CCTV untuk menggerakan nya dengan tangan,sehingga bisa lebih mudah dalam kendali CCTV. Alat pengamat manusia ini akan dikembangkan untuk dapat memberikan hasil yang lebih tepat dan akurat untuk dapat mendukung perkembangan teknologi dan informasi canggih saat sekarang ini. Sehingga alat ini akan sangat berguna dan membantu dalam dunia wira usaha terutama Perusahaan, Universitas dan lain lain.

\section{Tinjauan Pustaka}

\section{A. Rancang Bangun}

Menurut Devina dalamJogiyanto (2008:2), Rancang Bangun (desain) adalah tahap dari setelah analisis dari siklus pengembangan sistem yang merupakan pendefinisian dari kebutuhan-kebutuhan fungsional, serta menggambarkan bagaimana suatu sistem dibentuk yang dapat berupa penggambaran, perencanaan dan pembuatan sketsa atau pengaturan dari beberapa elemen yang terpisah ke dalam satu kesatuan yang utuh dan berfungsi, termasuk menyangkut mengkonfigurasikan dari komponenkomponen perangkat keras dan perangkat lunak dari suatu sistem.

Menurut Zaenal Arifin dalam Sutabri (2013:3), Bahwa sistemdapat di artikan sebagai suatu kumpulan atau himpunan dari unsur, komponen, atau variabel yang terorganisir, saling berinteraksi, saling bergantung satu sama lain, dan terpadu.

Menurut Halim dalam Arif (2013:7),yang dikutip dari (Roger S Pressman, Software Engineering A Practitioner's Approach( 2001) Dari sekian banyak definisi yang telah diusulkan, semua definisi tersebut mengacu pada pentingnya rancang-bangun dalam pengembangan software. Rancang-bangun perangkat lunak merupakan suatu pertumbuhan diluar perangkat keras dan rancang-bangun sistem. yang meliputi tiga kunci pokok yaitu: cara, alat dan prosedur yang memungkinkan manajer untuk mengendalikan proses pengembangan software dan menyediakan praktisi dengan tujuan untuk membangun perangkat lunak yang berkualitas. Metode rancang bangun perangkat lunak menyediakan cara teknis "bagaimana cara" untuk membangun perangkat lunak, caranya meliputi suatu rangkaian tugas yang meliputi: perencanaan proyek dan penilaian, analisa system dan software yang dibutuhkan, perancangan struktur data, perancangan program, dan algoritma program, pengkodean, pengujian, dan pemeliharaan.

\section{B. Analisa}

Menurut Devina dalam Rosa (2008:2), analisis adalah kegiatan untuk melihat sistem yang sudahberjalan, melihat bagian mana yang bagus dan tidak bagus, dan kemudian mendokumentasikan kebutuhan yang akan dipenuhi dalam sistem yang baru.

Menurut Rizal dkk dalam Syahrul (2013:10) Analisis adalah melakukan evaluasi terhadap kondisi dari pos-pos atau ayat-ayat yangberkaitan dengan akutansi dan alasan-alasan yang memungkinkan tentang perbedaan yang muncul. Dari beberapa macam uraian diatas bisa disimpulkan bahwa analisis adalah kegiatan berfikir untuk menguraikan suatu pokok menjadi bagian-bagian atau komponen sehingga dapat di ketahui ciri atau tanda tiap bagian, kemudian hubungan satu sama lain serta fungsi masing-masing bagian dari keseluruhan.

Menurut Saputra (2015:88), Analisa sistem adalah penguraian dari suatu sistem informasi yang utuh ke dalambagian-bagian komponennya dengan maksud untuk mengidentifikasi dan mengevaluasi 
permasalahan, kesempatan-kesempatan, hambatanhambatan yang terjadi dankebutuhan-kebutuhan yang diharapkan sehingga dapat diusulkan perbaikanperbaikannya. Tahap ini merupakan tahap yang kritis dan sangat penting, karena kesalahan di tahap ini akan menyebabkan kesalahan juga di tahap selanjutnya.

Menurut Nugroho dalam Jogiyanto (2012:5), analisa sistem adalah penguraian dari suatu sistem informasi yang utuh kedalam bagian-bagian komponennya dan dengan maksud untuk mengidentifikasi dan mengevaluasi permasalah, kesempatan, hambatan yang terjadi dan kebutuhan yang diharapkan sehingga dapat diusulkan perbaikanperbaikannya.

\section{Pengendali}

Menurut Patiung dkk (2013:2), Sistem kontrol adalah suatu proses pengaturan / pengendalian terhadap satu atau beberapa besaran (variabel, parameter) sehingga berada pada suatu harga atau dalam rangkuman harga (range) tertentu. Dalam istilah lain disebut juga sistem pengaturan, sistem pengendalian atau sistem pengontrolan. Ditinjau dari segi peralatan dan instrumen yang digunakan, sistem kontrol terdiri dari berbagai susunan komponen fisik yang digunakan untuk mengarahkan aliran energi ke suatu mesin atau proses agar dapat menghasilkan prestasi yang diinginkan.

Menurut Kurniawan dalam Ahmad (2016:5), Teknologi kendali jarak jauh merupakan teknologi yang berhubungan dengan interaksi antar manusia dengan system secara otomatis dari jarak yang jauh. dalam sistem kendali jarak jauh, secara garis besar terdapat dua buah komponen utama yaitu bagian pengendali lokal dan bagian pengendali sisi jauh. Pengendali lokal merupakan bagian pengendali oleh operator, yaitu bagian dimana pengotrol memberikan akses kendalinya, sedangkan bagian pengendali sisi jauh adalah bagian yang berhubungan langsung dengan peralatan yang dikendalikan.

\section{Android}

Menurut Desmira dkk dalam Waloeya (2016:7). Android adalah sistem operasi untuk telepon seluler yang berbasis Linux. Android menyediakan platform terbuka bagi para pengembang buat menciptakan aplikasi mereka sendiri untuk digunakan oleh bermacam peranti bergerak. Awalnya, Google Inc. membeli Android Inc, pendatang baru yang membuat peranti lunak untuk ponsel. Kemudian untuk mengembangkanAndroid, dibentuklah Open Handset Alliance, konsorsium dari 34 perusahaan peranti keras, peranti lunak, dan telekomunikasi, termasuk Google, HTC, Intel, Motorola, Qualcomm, T-Mobile, dan Nvidia. Android adalah sistem operasi berbasis linux yang digunakan untuk ponsel (telepon seluler) mencakup sistem operasi, middleware dan aplikasi.

Menurut Giyartono dkk dalam Nazruddin (2015:2) Android adalah sebuah sistem operasi untuk perangkat mobile berbasis linux yangmencakup sistem operasi, middleware dan aplikasi. Android menyediakan platform terbuka bagi para pengembang untuk menciptakan aplikasi mereka".

Menurut Sari dalam M. Ichwan (2015:151) Android adalah sistem operasi berbasis kernel Linux yang pada awalnyadikembangkan oleh Android, Inc, yang didukungGoogle finansial dan kemudian dibeli pada tahun2005. Android ini diresmikan pada tahun 2007 seiringdengan berdirinya Open HandsetAlliancekonsorsium hardware, software, dan perusahaan telekomunikasi yang ditujukan untuk memajukan standar perangkat selular.

\section{E. Smartphone}

Menurut Desmira dkk dalam (Mayasari (2016:7), Software Aplikasi pada telepon seluler pintardikembangkan oleh operator dari device itu sendiri ataupun pihak ketiga yang ikut mengembangkan untuk kepentingan komersial. "Smartphone adalah sebuah device yangmemungkinkan untuk melakukan komunikasi 
(sepertimenelepon atau sms) juga di dalamnya terdapat fungsi PDA (Personal Digital Assistant) dan berkemampuan seperti layaknya komputer." Sistem operasi yang digunakan pada telepon seluler pintar berbeda - beda tetapi yang paling banyak digunakan saat ini adalah sistem operasi yang berbasis.

Menurut Kurniawan dalam Chuzaimah (2016:9). Smartphone atau ponsel cerdas merupakan kombinasi pada PDA dan ponsel, namun lebih berfokus pada bagian posel. smartphone ini mengintegrasikan kemampuan ponsel dengan fitur komputer - PDA. Smartphone mampu menyimpan informasi, e-mail, dan intalasi program, seperti menggunakan mobile phone dalam satu device.

\section{F. Bluetooth HC-06}

Menurut Sari dalam Pratama (2015:151) BluetoothHC-06 adalah sebuah modul Bluetooth SPP (Serial PortProtocol) yang mudah di gunakan untuk komunikasi serial wireless (nirkabel) yang mengkonversi portserial ke Bluetooth. HC-06 menggunakan modulasibluetooth V2.0 + EDR Enchanced Data Rate) 3 Mbps dengan memanfaatkan gelombang radio berfrekuensi 2,4 GHz. Dalam penggunaanya HC-06 dapat beroperasi tanpa menggunakan driver khusus. Jarak sinyal dari HC-06 adalah 30 meter, dengan kondisi tanpa halangan. Untuk berkomunikasi antar Bluetooth, minimal harus memenuhi dua kondisi berikut:

1. Komunikasi harus antara master dan slave.

2. Password harus benar (saat melakukan pairing).

Menurut Kristanto (2013:227). Bluetooth adalah spesifikasi industri untuk jaringan untuk kawasan pribadi (personal area network atau PAN) tanpa kabel. Bluetooth beroperasi dalam pita frekuensi $2.4 \mathrm{GHz}$ dengan menggunakan sebuah frequency hopping transceirver yang mampu menyediakan layanan komunikasi data dan suara secara real time antara host bluetooth dengan jarak terbatas. Bluetooth module adalah modul bluetoothdevice yang dipakai untuk menghubungkan mikrontroler dengan smartphone.

\section{G. Closed Circuit Television}

Menurut Sumajouw (2015:45). CCTV (Closed Circuit Television) merupakan sebuah perangkat kamera video digital yang digunakan untuk mengirim sinyal kelayar monitor di suatu ruang atau tempat tertentu. Hal tersebut memiliki tujuan untuk dapat memantau situasi dan kondisi tempat tertentu. Pada umumnya CCTV seringkali digunakan untuk mengawasi area public. Awalnya gambar dari kamera CCTV hanya dikirim melalui kabel ke sebuah ruang monitor tertentu dan dibutuhkan pengawasan secara langsung oleh operator/petugas keamanan dengan resolusi gambar yang masih rendah. Namun seiring dengan perkembangan teknologi yang sangat pesat seperti saat ini, banyak kamera CCTV yang telah menggunakan sistem teknologi yang modern. Sistem kamera CCTV digital saat ini dapat dioperasikan maupun dikontrol melalui Personal Computer atau Telephone genggam, serta dapat dimonitor dari mana saja dan kapan saja selama ada komunikasi dengan internet maupun akses GPRS.Elemen - elemen CCTV (Closed Circuit Television) berikut :

Keberhasilan sistem CCTV ditentukan oleh kualitas elemen-elemen yang mendukung sistem tersebut diantaranya adalah:

1. Kamera: Berdasarkan kategori bentuk terbagi menjadidua macam yaitu fixed camera (Posisi Kamera tidak bisa berubah ubah) dan PTZ (Pan Tilt Zoom) camera (Posisi Kamera dapat berubah dan dapat di zoom)

2. Media Transmisi: Media transmisi dari CCTV menggunakan kabel koaksial atau UTP sedangkan wireless menggunakan acces point berupa Router.

3. Monitor: menampilkan objek yang ditangkap oleh kamera.

4. Aplikasi piranti lunak: suatu aplikasi yang dapat mengontrol CCTV dari suatu tempat dan dapat 
diintergrasikan dengan server penyimpanan video.

5. Media Penyimpanan: DVR (Digital Video Recorder) atau Hardisk

Menurut Hadiwijaya (2014:1). CCTV (Closed Circuit Television) adalah suatu alat yangdapat mengirimkan informasi video transmisi melalui kelokasi tertentu yang dipasang di suatu tempat sepertidalam ruangan yang ingin dapat dilihat secara real time, Pada umumnya fungsi dari CCTV adalah sebagaipemantaubaik pada bidang keamanan ataupun industriKebutuhan manusia akan sistem pemantauan terusmeningkat seiring dengan perkembangan teknologi yangsemakin canggih. Perangkat kamera pun beralih darikamera yang menggunakan kabel kamera analog menujukamera nirkabel (wireless) yaitu webcam Kelebihankamera webcam ini sistem mampu memantau kondisiruangan dari jarak jauh selain dapat merekam videosecara manual.dan dapat dikembangkan dengan fiturdapat mendeteksi adanya suatu gerakan.

\section{H. IP camera}

Menurut Mahatma dkk Innes (2010:12), Pengertian IP Camera merupakan perkembangan dariCCTV. Yang membedakannya dengan CCTV biasa F-12 adalah setiap kamera memiliki IP sendiri sehingga kita bisa memilih kamera mana yang mau dilihat,IP Camera memungkinkan pemilik rumah dan bisnis untuk melihat kamera mereka melalui koneksi internet yang tersedia baik melalui computer maupun mobile phone yang mendukung $3 \mathrm{G}$.

\section{Motor Servo}

Menurut Giant dkk (2015:72), Motor servo adalah motor servo yang dilengkapi dengan sistem kontrol. Sistem kontrol ini akan memberikan umpan balik posisi perputaran motor dari 0 sampai 180 derajat. Disamping itu motor ini juga memiliki torsi relatif cukup kuat. Sistem pengkabelan motor servo terdiri atas 3 bagian, yaitu Vcc, Gnd, dan Kontrol (PWM= Pulse WidthModulation). Pemberian PWM pada motor servo akan membuat servo bergerak pada posisi tertentu dan kemudian berhenti (kontrol posisi). Prinsip utama dari pengendalian motor servo adalah pemberian nilai PWM pada kontrolnya. Frekuensi PWM yang digunakan pada pengontrol motor servo selalu $50 \mathrm{~Hz}$ sehingga pulsa dihasilkan setiap $20 \mathrm{~ms}$. Lebar pulsa akan menentukan posisi servo yang dikehendaki. Pemberian lebar pulsa 1,5 ms akan membuat motor servo berputar ke posisi netral $(90$ derajat), lebar pulsa 1,75 ms akan membuat motor servo berputar 1 derajat mendekati posisi 180 derajat, dan dengan lebar pulsa 1,25 ms motor servo akan bergerak ke posisi 0 derajat. Gambar 4 berikut memperlihatkan hubungan antara lebar pulsa PWM dengan arah putaran motor servo.

Menurut Scolichul Amri dalam averroes (2010:14). Motor servobiasanya digunakan untuk robot berkaki, berlengan atau sebagai actuator pada mobile robot. Motorservo terdiri dari sebuah motorDC, beberapa gear, sebuah potensiometer, sebuah output shaft dan sebuahrangkaian control elektronik. Motor servo dikemas dalam bentuk segi empatdengan sebuah output shaft motor dan konektor dengan 3 kabel yaituground, power dan control.

\section{J. Mikrokontroller}

Menurut Giyartono dkk dalam Djuandi (2015:2) Arduino adalah kit elektronik atau papan rangkaian elektronik open source yang didalamnya terdapat komponen utama yaitu sebuah chip dengan jenis AVR dari perusahaan Atmel. Arduino dikatakan sebagai sebuah platform dari physical computing yang bersifat open source. Pertama-tama perlu dipahami bahwa kata "platform" disini adalah sebuah pilihan kata yang tepat. Arduinotidakhanya sekedar sebuah alat pengembangan, tetapi kombinasi dari hardware, bahasapemrograman dan Integrated Development Environment (IDE) yang canggih. IDE adalahsebuah 
software yang sangat berperan untukmenulis program, meng-compile menjadi kode biner dan meng-upload ke dalam memory mikrocontroller. "Komponen utama didalam papan Arduinoadalah sebuah 8 bit dengan merk Atmegayang dibuat oleh Atmel Corporation. Berbagaipapan Arduino menggunakan tipe Atmegayang berbeda-beda tergantung darispesifikasinya., sebagai contoh Arduino nano menggunakan ATmega328 sedangkan ArduinoMega 2560 yang lebih canggih menggunakanAtmega2560.”

Microcontroller adalah komponen elektronika yang berukuran kecil yang berfungsi sebagai pengendali yang di dalamnya terkandung sistem interkoneksi antara microprocessor, RAM, ROM, CPU, input, dan output. Menurut pratama dalam Shankara (2015:13) menyatakan bahwa: Microcontroller is as technology moved from LSI to VLSI, it become posibble to build the microprocessor, memory and I/O devices on single chip. This came to be known as the 'microcontroller'. A microcontroller contains a microprocessor andalso one or more of the following components.

1. Memory

2. Analog to Digital (A/D) converter

3. Digital to Analog (D/A) converter

4. Parallel $\mathrm{I} / \mathrm{O}$ interface

5. Serial $\mathrm{I} / \mathrm{O}$ interface

6. Timers and Counters

Microcontroller merupakan komputer di dalam chip yang digunakan untuk mengontrol peralatan elektronik, yang menekankan efisiensi dan efektifitas biaya Secara teknis microcontroller terbagi 2 jenis yaitu RISC dan CISC yang masing-masing mempunyai keluarga. RISC (Reduced Instruction Set Computer) yaitu instruksi terbatas namun dengan fasilitas yang lebih banyak. CISC kepanjangan dari (Complex Instruction Set Computer) yaitu instruksi lebih lengkap namun dengan fasilitas terbatas. Jadi, microcontroller adalah sebuah alat yang mengerjakan instruksi yang dibuat oleh programmer. Program menginstruksikan microcontroller untuk melakukan jalinan yang panjang dari aksi - aksi sederhana untuk melakukan tugas yang lebih kompleks sesuai keinginan programmer.

\section{K. Hardware (Perangkat Keras)}

Menurut Roziman dalam Mulyono (2014 :23), Hardware (Perangkat Keras) adalah sekumpulan komponen perangkat keras didalam komputer yang secara fisik dapat dilihat, diraba dan dirasakan.

\section{Software (Perangkat Lunak)}

Menurut Sudrajat dalam Adjri (20013: 14) Software (Perangkat lunak) komputer adalah suatu perangkat yang berisi serangkaian instruksi, program, prosedur, pengendali pendukung, dan aklifitas-aktifitas pengolahan perintah pada sistem komputer. Jadi software komponen merupakan komponen abstrak dari susunan sistem komputer secara umum fungsi dari software yang utama.

\section{Sistem Operasi}

Merupakan sistem software yang berfungsi untuk mengatur kinerja komputer secara mendasar seperti mengatur media input-proses-output, mengatur penjadwalan prosesor. Contoh sistem operasi: windows, linux, unik dan sebagainya

\section{Bahasa pemrogramanan}

Merupakan perangkat lunak yang bertugas mengkonversikan arsitektur dan alogaritma yang dirangcang manusia kedalam format yang dijalankan komputer, contoh bahasa pemrograman: $\mathrm{C}++$, DELPHI, VISUALBASIC, dan sebagainya.

\section{Brainware (Pengguna)}

Menurut Roziman dalam Mulyono (2014:24) Brainware (Pengguna) adalah orang yang mengoperasikan dan menjalan Software yang ada didalam komputer, contohnya mengetik surat dengan menggunakan Microsoft Word, membuat program aplikasi perusahaan dan memperbaiki komputer. 


\section{Metodologi Penelitian}

Metode penelitian yang digunakan adalah metode eksperimen, dimana dalam penelitian akan dibuat Pengendali CCTV Menggunakan motor servo berbasis Arduino Nano. Alat ini terdiri dari satu pengendali CCTV yang menggunakan Borduino, Arduino, Motor servo, Ip Camera dan PC (Personal display) Setelah semua bahan untuk membuat alat telah siap maka kita akan merangkai alat-alat tersebut, sampai alat tersebut aktif dan bisa digunakan sesuai dengan kegunaanya. Metode penelitian yang dilakukan studi literature dan eksperimen laboratorium. Penelitian yang dilakukanakan terfokus pada komunikasi antara perangkat smartphone dengan mikrokontroler Arduino melalui Bluetooth untuk mengendalikan perangkat elektronik. Dari hasil eksperimen nantinya akan disimpulkan tentang fungsi dari pengendalian CCTV dengan smartphone menggunakan koneksi Bluetooth.

\section{A. Metode Pengumpulan Data}

Data penelitian yang diperlukan dalam penyusunan laporan tugas diperoleh melalui metode studi pustaka studi laboratorium.

\section{Studi Pustaka}

Data penalitian pada metode studi pustaka diperoleh dari sumber pustaka yang meliputi buku, majalah atau arsip mengenai topik yang dibahas dalam penelitian. Data penelitian ini juga diperoleh dari internet. Buku yang digunakan berupa buku konsep, atau handbook computer elektronica, majalah yang dijadikan rujukan adalah majalah komputer dan jumal ilmiah.

\section{Studi Laboratorium}

Data penelitian pada metode studi laboratorium diperoleh melalui praktikum dan uji coba. Percobaan yang dilakukan meliputi test bahasa pemrograman, uji komponen elektronika dan uji perangkat keras komputer yang cocok untuk pelaksanaan penelitian.

\section{B. Metode Perancangan Sistem}

\section{Diagram Blok Global}

Diagram Blok global dari rangkaian alat dapat dilihat pada gambar sebagai berikut:

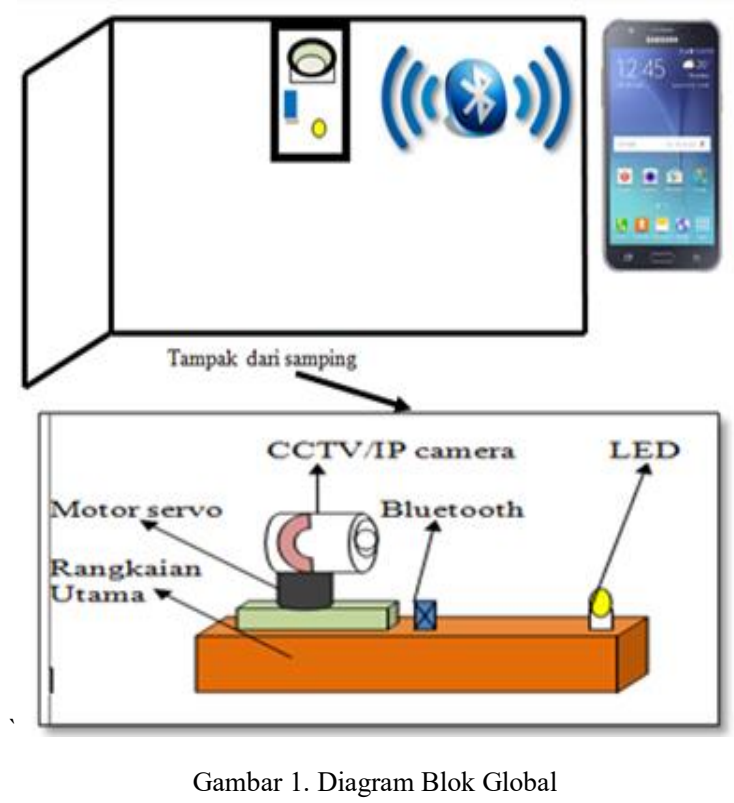

\section{Diagram Blok Rangkaian Alat}

Gambar 2 adalah gambar dari diagram rangkaian alat. Blok diagram rangkaian rancang bangun dan analisa pengendali CCTV berbasis arduino menggunakan smartphone android.

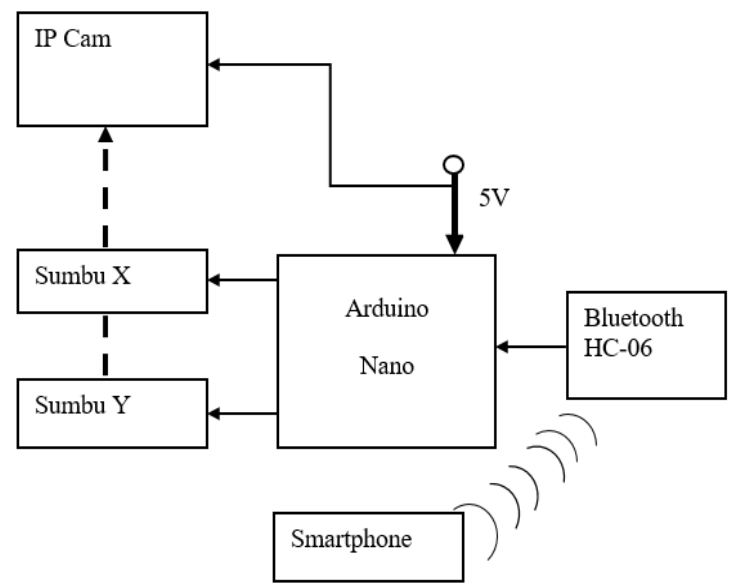

Gambar 2. Blok Diagram Rangkaian Alat

Smartphone android berfungsi sebagai pengendali IP Camera (CCTV) memanfaatkan sebuah teknologi komunikasi nirkabel yang akan terhubung pada modul bluetooth. 
Arduino nano berfungsi Sebagai pengolahan data berupa program yang diupload dari komputer dengan menggunakan serial USB.

Komputer, digunakan sebagai perancangan program untuk pengendali CCTV (IP Camera) bluetooth berbasis Arduinonano.

Motor Servo digunakan untuk pengendali IP Camera.

\section{Desain Rangkaian Alat}

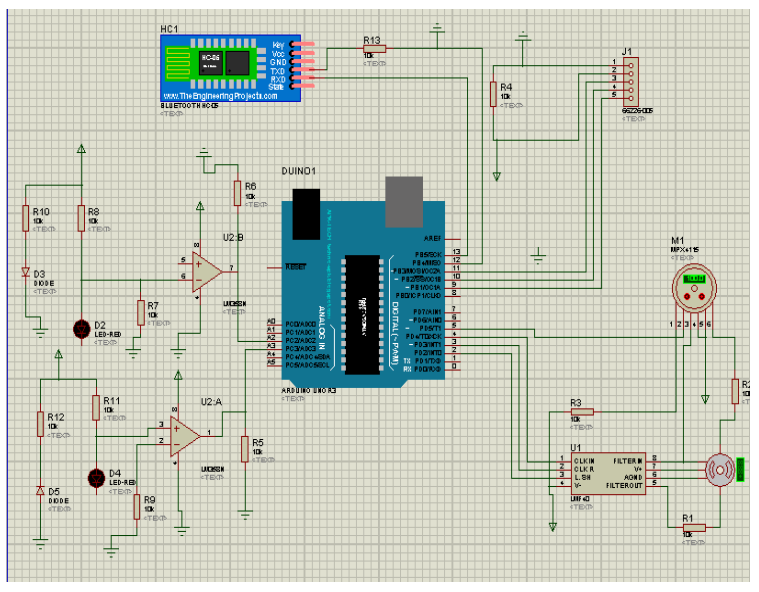

Gambar 3. Desain Rangkaian

Modul Bluetooth yang berfungsi sebagai penerima peintah dari Smartphone dengan menngunakan komunikasi. Bluetooth dapat dipakai untuk melakukan komunikasi data di antara smartphone dengan arduino dengan jarak jangkauan yang cukup jauh.

Arduino nano memiliki 14 digital pin untuk input / output ( atau biasa ditulis $\mathrm{I} / \mathrm{O}$, dimana 6 pin di antaranya dapat digunakan sebagai output PWM), 6 pin input analog menggunakan crystal $16 \mathrm{MHz}$, koneksi USB, jack listrik header ICSP dan tombol reset.

\section{Prinsip Kerja Sistem}

Prinsip pengendalian robot Bluetooth membutuhkan 1-unit smartphone yang berfungsi sebagai pengirim perintah control arah gerak dengan mengirim data Bluetooth dalam sistem aplikasi control Bluetooth. Didalamnya sudah diberikan data logika yang akan dikirimkan melalui HC-06 dan masuk kedalam sistem mikrokontroler yaitu Arduino nano.
Arduino nano akan bekerja berdasarkan alur perangkat lunak. Data yang sudah diolah oleh Arduino nano akan membuat keluaran pada PORT berlogika dan memberikan data pada Ada fruit Motor shield, lalu motor servo akan menentukan arah putar motor.

\section{Hasil dan Pembahasan}

\section{A. Hasil}

\section{Pembuatan Alat}

Hasil rancang bangun dan analisa pengendali CCTV berbasis arduino menggunakan smartphone android, pada pengendali CCTV ini menggunakan Arduino Nano sebagai sistem pengendalian Bluetooth, modul Bluetooth digunakan sebagai penerimaan perintah yang dikirim melalui smartphone android dan motor servo difungsikan sebagai penggerak CCTV yang dikendalikan menggunakan Smartphone Android menggunakan aplikasi arduino two servo motors controls sehingga bisa dikendalikan dengan jarak yang cukup maxsimal aplikasi ini diinstall melalui Playstore. Dalam penelitian ini penulis mendapatkan hasil sebagai berikut :

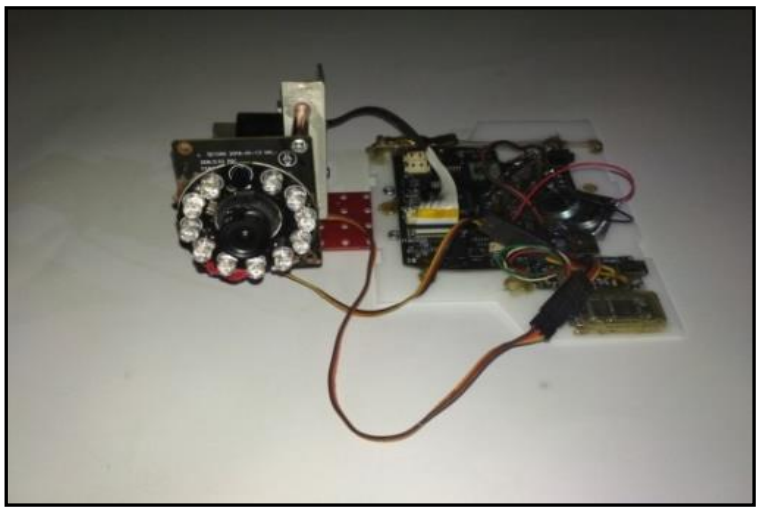

Gambar 4. Tampilan Robot Penjejak Sinar Matahari

\section{Aplikasi Alat}

Pengendali cctv ini menggunakan aplikasi pada playstore yang listing programnya dicocokan kek aplikasi tersebut.Aplikasi pengendali cctv terdapat beberapa bagian pengendali rotasi yaitu sumbu $\mathrm{X}$ dan sumbu Y sebagai (horizoltal dan vertikal rotasi). 


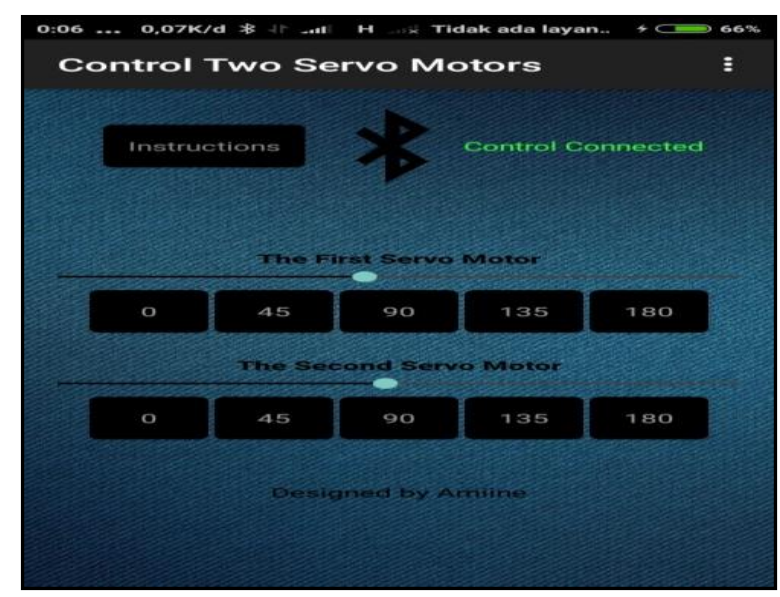

Gambar 4.2 Tampilan Aplikasi pada smartphone

\section{Prosedur Mengoperasikan}

Pengendali cctv ini bekerja dengan menghubungkan aplikasi pada smartphone android dan bekerja sesuai intruksi. Adapun prosedur untuk mengoperasikan alat ini adalah sebagai berikut:

1. Menghidupkan bluetooth pengendali cetv dan smartphone android

2. Menghubungkan pengendali cctv ke smartphone android

3. Menyambungkan koneksi antara modul bluetooth dan smartphone android

4. Menjalankan aplikasi pada smartphone android.

5. Setting port perintah sumbu $X$ (the first servo motor) berfungsi untuk melakukan kendali dari kiri ke kanan.

6. Setting port perintah sumbu Y (the second servo motor) berfungsi untuk melakukan kendali dari atas ke bawah.

7. Data masuk adalah menghasilkan proses pengiriman data dari alat (mikrokontroler arduino nano) ke aplikasi di smartphone android.

\section{B. Pembahasan}

\section{Persiapan Alat dan Bahan}

Pembuatan Robot ini dilakukan dengan mengumpulkan alat dan bahan, kemudian dilakukan proses merangkai alat. Adapun alat yang digunakan dalam merangkai alat yaitu :
2. Alat Yang Digunakan Dalam Merangkai Alat

1. Gunting untuk memotong kabel

2. Tang untuk memotong kaki dan pin dari komponen dan bahan dalam proses merangkai alat.

3. Obeng digunakan untuk memasang mur, baut memasang komponen dan rangkaian.

4. Alat ukur yaitu multimeter untuk mengukur komponen dan bahan yang digunakan dalam merangkai alat.

5. Timah digunakan untuk melekatkan komponen diatas papan PCB.

6. Isolator atau Lakban digunakan untuk memberikan lapisan penghalang antara komponen dan untuk melapisi sambungan kabel.

7. Solder digunakan untuk menyolder komponen diatas papan PCB.

\section{Bahan yang digunakan dalam merangkai alat}

Adapun bahan, komponen dan fungsinya yang digunakan dalam merangkai alat yaitu :

1. Modul bluetooth berfungsi untuk mengkoneksikan perintah dari smartphone ke arduino.

2. IC (Integrated Circuit), IC yang digunakan dalam rangkaian robot yaitu IC dengan tipe max232. IC ini berfungsi untuk jembatan komunikasi serial antara mikrokontroler dengan komputer.

3. Mikrokontroler Arduino nano digunakan untuk mengolah data yang dikirim modul bluetooth ke alat.

\section{Software yang digunakan dalam aplikasi}

Adapun software yang digunakan dalam aplikasi yaitu Arduino two servo motor controlsdan pemrograman software IDE arduino.

\section{Perancangan CCTV}

Kegiatan merangkai alat dilakukan dengan mempersiapkan alat dan bahan dan merangkai dengan cara menyolder diatas papan rangkaian. Adapun 
langkah-langkah pembuatan alat yang telah dilakukan yaitu :

1. Membuat rangkaian modul bluetooth yang berfungsi sebagai sumber pengendalian pada mikrokontroler dan smartphone.

2. Merangkai mikrokontroler arduino nano dengan motor servo mg90s.

3. Merangkai komunikasi dengan meggunakan IC $\max 232$ atau proses upload data ke arduino dengan modul.

Setelah semua komponen dirangkai berikutya dilakukan proses pengujian alat. Dari hasil pengujian sementara pengendali cctv dapat berfungsi untuk mengendalikan dari jarak yang ditentukan yang masuk pada ruang tertutup maupun terbuka menggunakan modul bluetooth

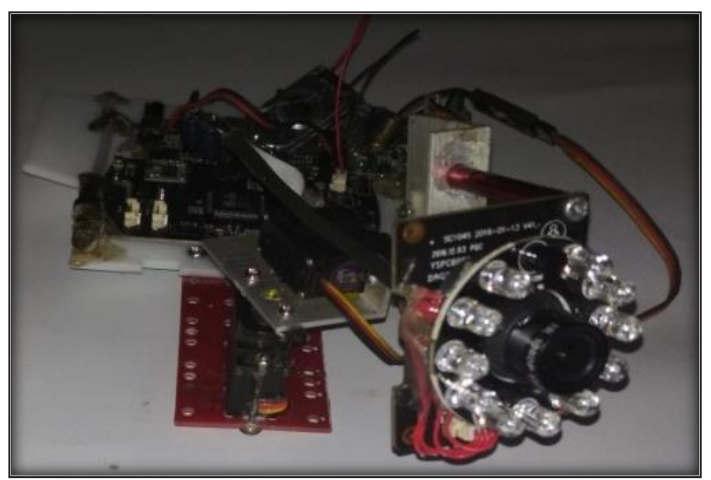

Gambar 4.4 Rangkaian alat pengendali cctv

\section{Persiapan Program}

Hasil yang di peroleh dalam menggunakan aplikasi Arduino IDE ini berupa listing program dimana kita akan mengetahui kode program yang akan dikirim dan diterima oleh Smartphone dan modul Bluetooth HC-06 dalam pengendalian CCTV yang di upload kedalam mikrokontroller arduino Nano dengan menggunakan sebuah PC dan bahasa pemograman sketch. Kode program ini dapat diketahui ketika menekan arah pada oengendali bluetooth pada smartphone android dan terhubung pada modul Bluetooth HC-06 yang akan menggerakan CCTV, program ini dapat dilihat pada gambar 4.5 dan untuk lebih jelasnya lagi bisa dilihat pada lampiran.

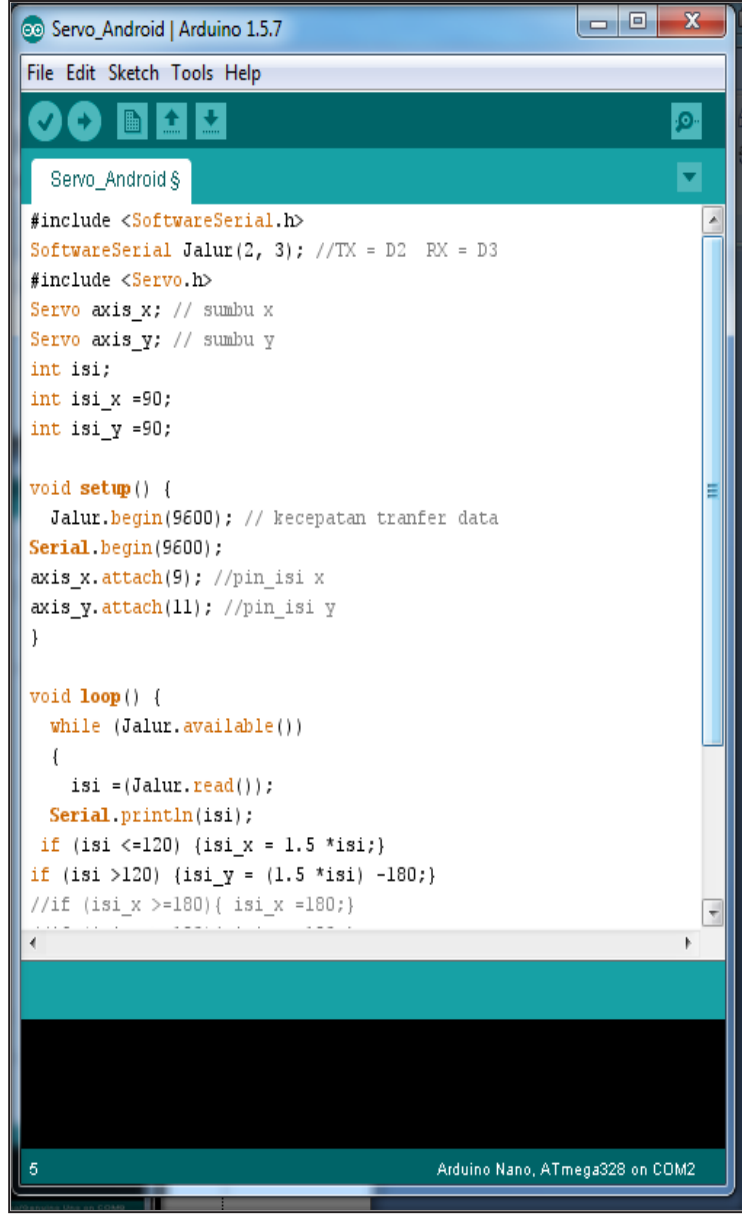

Gambar 4.5 pembuatan Sketsa program

\section{Program Arduino IDE}

Arduino IDE adalah software yang sangat canggih ditulis dengan menggunakan Java. IDE Arduino terdiri dari:

1. Editor program, sebuah windows yang memungkinkan pengguna menulis dan mengedit program dalam bahasa Processing.

2. Compiler, sebuah modul yang mengubah kode program (bahasa Processing) menjadi kode biner. Bagaimana pun sebuah microcontroller tidak akan bias memahami bahasa Processing. Yang bias dipahami oleh microcontroller adalah kode biner. Itulah sebabnya compiler diperlukan dalam hal ini.

3. Uploader, sebuah modul yang memuat kode biner dari computer kedalam memori didalam papan Arduino.

Sebuah kode program Arduino umumnya disebut dengan istilah sketch. Kata "sketch" digunakan secara 
bergantian dengan "kode program" dimana keduanya memiliki arti yang sama.

\section{Penutup}

\section{A. Kesimpulan}

1. Berdasarkan koneksi antara pengendali cctv Bluetooth dan smartphone android dapat diketahui jarak maksimalnya sebesar 25 meter dan status terhubung sebagian pengendali cetv masih bisa dikendalikan.

2. Berdasarkan koneksi antara pengendali cetv Bluetooth dan smartphone android dalam jarak40 meter cctv tidak bisa dikendalikan.

3. Berdasarkan kualitas gambar dapat diketahui tampak stabil dan jernih maksimal jarak 25 meter gambar masih tampak terang, lebih dari 25 meter gambar akan mengalami kualitas kurang baik, hasil yang paling jenih pada jarak sekitaran 10 meter gambar akan jelas dan stabil kualitas baik.

\section{B. Saran}

Berdasarkan hasil pengujian dan hasil analisa yang telah penulis lakukan maka penulis memiliki saran agar alat ini dapat dikembangkan lagi yang memiliki teknologi yang lebih canggih seperti menambahkan modul internet yang bisa menambahkan fitur online dan menambahkan fungsi keamanan alarm yang akan lebih canngih pengendaliannya untuk kedepannya tetap menggunakan arduino nano yang masih baik untuk digunakan.

\section{Daftar Pustaka}

Arifin Jauhari, Leni dan Hermawansyah. 2016. Perancangan Murottal Otomatis menggunakan Mikrokontroler Arduino Mega 2560 jurnal Media Infotama. 2016, (93), $1858-2680$

Alfith. 2015. Perancangan Traffic Light Berbasis Microcontroller Atmega 16 Jurnal Momentum. 2015, (3), 1693-752X

Febri. 2015. Pembuatan Alat Pengecas Elektronik dengan Energi Sel Surya. Tesis tidak diterbitkan. Bengkulu. Program Pasca Sarjana Universitas Dehasen Bengkulu. 34 hal
Desmira, Ahmad dan Fajar. 2016. Perancangan Smartphone dengan Rasberry Berbasis Wireless menggunakan Mikrokontroller dan Fuzzylogic (pada Mess PLTU Labuan) jurnal prosisko. 2016, (7), 2406-7733

Devina Ria A. 2008. Analisis dan Rancang Bnagun Sistem Informasi Pengolahan Data Pembayaran Kredit Rumah Berjangka pada PT Pulau Jaya Abadi Palembang menggunakan Pemrograman Delphi 2007 dan SQL server 2008. Palembang. Jurusan Sistem Informasi STMIK Palcom tech. 12 hal

Giyartono Andik, Priadhana. 2015. Aplikasi Android Pengendali Lampu Rumah Berbasis Mikrokontroler Atmega328 jurnal. ftumj. 2015, (2), 2407-1846

Giant Ragil, Darjat dan sudjadi. 2015. Perancangan Aplikasi Pemantau dan Pemantau Pengendali Piranti Elektronik pada Ruangan Berbasis Web Jurnal Transmisi. 2015, (72), 2407-6422

Hadiwijaya Bambang, Darjat dan Ajub. 2014. Perancangan Aplikasi CCTV sebagai pemantau ruangan menggunakan IP camera Jurnal teknik elektro. 2014, (1), 2302-9927

Halim. 2013. Rancang Bangun Sistem Informasi Penyewaan pada Rental Mobil Berbasis Web dan menggunakan SMS Gateway. Skripsi tidak diterbitkan. Kudus. Program Pasca Sarjana Universitas Muria Kudus. 84 hal

Iskandar Abdullah, Agus. 2013. Evaluasi penggunaan Lampu LED sebagai pegganti Lmapu Konvensional Jurnal Teknik Elektro. 2013, (16), 2502-0986

Kurniawan Nudi ,2016 Kendali robot bluetooth dengan smartphone android berbasis Arduino Uno.Bengkulu. Universitas Dehasen Bengkulu. 44 hal

Kristanto johannes, lukas. 2013. Rancang bangun robot pemantauruangan melalui bluetooth dengan mobile phone berbabasis android. UKRIDA. 15 hal

Nugroho Irawan. 2012. Analisis dan Perancangan Sistem Informasi Penjualan Toko Online Wara Computer Yogyakarta. Yogyakarta. Sekolah tinggi Manajemen Informatika dan komputer amikom. 15 hal

Patiung Fajar, Arie dan Lumenta. 2013. Rancang Bangun Robot Beroda dengan Pengendali Suara e-journal Teknik Elektro dan Komputer. 2013, (2), 1-5

Pratama. 2015 . Pengembangan Midi Controller Berbasis Microcontroller dengan Mekanisme sentuh.Yogyakarta. Universitas Negeri Yogyakarta. 102 hal

Prayudha Jaka, Dikcy dan Iksan. 2014. Otomatisasi Pendekteksi Jarak Aman dan Intensitas Cahaya dalam Menonton Televisindengan Metode Perbandingan Diagonal Layar Berbasis Mikrokontroler Atmega 8535 Jurnal ilmiah saintikom. 2014, (176), 1978-6603

Putra Samuel Mahatma, Handoko dan Rika. 2010. Analisis dan Perancangan Aplikasi Monitoring IP Camera 
menggunakan Protokol HTTP PADA Mobile Phone Seminar Nasional Aplikasi Teknologi Aplikasi. 2010, (12), 1907-5022

Rizal Irhas, Riski dan Fahmi. 2013. Analisis Sistem Informasi Akademik Online di Universitas Diponegoro Semarang Laporan Kuliah Kerja Praktek. Semarang: Universitas Bina Darma. 57 hal

Roziman. 2014. Alat Mematikan dan Menghidupkan Televisi dengan Message Service (SMS) Menggunakan Mikrokontroler Atmega 32. Tesis tidak diterbitkan. Bengkulu. Skripsi tidak diterbitkan. Universitas Dehasen Bengkulu. 49 hal

Saputra Rusli. 2015. Desain Sistem Informasi Order Photo Pada Creative Studio Photo dengan menggunakan Bhasa Pemrograman Visual Basic.Net 2010 Jurnal Momentum. 2015, (88), 1693-752X

Sari Hesti Yupita, Prama Wira dan Yanolanda. 2015. Papan Informasi Digital Dinamis Berbasis Atmega 8535 dengan Media Perantara Bluetooth Dilaboratorium Hadware Universitas Dehasen Bnegkulu Jurnal Media Infotama, 2015(151) , $1858-2680$

Scolichul Amri. 2010. Sensor Uvtron sebagai Pendekteksi Api pada Robot Pemadam Api Berbasis Mikrokontroler Atmega 8535. Surakarta. Universitas Sebelas Maret. 46 hal

Sudrajat Yoyo. 2013. Modifikasi Kipas Angin dengan Kendali Sensor Laser. Tesis tidak diterbitkan. Bengkulu. Program Pasca Sarjana Universitas Dehasen Bengkulu. 46 hal

Sumajouw Davis F, Meicsy dan Najoan. 2015. Perancangan Sistem Keamanan Rumah Tinggal Terkendali Jarak Jauh journal Teknik Elektro dan Komputer. 2015, (45), 23018402

Zulfiandri, Sarip Hidayatuloh dan Mochammad. 2014. Rancang Bangun Aplikasi Politeknik Gigi (Studi Kasus : Politeknik Gigi Kejaksaan Agung RI) Jurnal Universitas Gunadarma. 2014, (474), 2302-3740 